\title{
Microbial Content Test on Sliced Papaya in Area of Universitas Sumatera Utara
}

\author{
Nenni Dwi Aprianti Lubis ${ }^{1}$, Sri Amelia ${ }^{2}$, Ridwan Balatif ${ }^{3}$ \\ ${ }^{1}$ Departemen Gizi, Fakultas Kedokteran, Universitas Sumatera Utara \\ ${ }^{2}$ Departemen Mikrobiologi, Fakultas Kedokteran, Universitas Sumatera Utara \\ ${ }^{3}$ Program Pendidikan Profesi Dokter, Fakultas Kedokteran, Universitas Sumatera
}

\begin{abstract}
Papaya is a fruit that is often consumed in Indonensia and has increased consumption from 2015-2016. Papaya has high water content (85-90\%) and the $\mathrm{pH}$ is near-neutral. This makes papaya a vulnerable and suitable medium for the growth of pathogenic microbes. The presence of pathogenic microbes in papaya can cause health problems. This study was to observe the microbial content of sliced papaya in the Universitas Sumatera Utara. This research was carried out by conducting laboratory tests and the results obtained in the form of a description of microbial content in papaya cut samples. The content of coliform microbes in sample was tested using the Most Probable Number (MPN) method and biochemical identification. A total of 14 sliced papaya samples were analysed in this study. By using the MPN test it was found that all papaya samples had a microbial threshold exceeding those determined by SNI 7388: 2009 which is below <20 / g. A total of 9 papaya samples $(64.28 \%)$ contained Klebsiella sp. bacteria, 5 samples $(35.72 \%)$ contained E.coli bacteria. The presence of microbial content in the sliced papaya sample that exceeds the threshold must be a concern of various parties in the surveillance of snacks being sold.
\end{abstract}

Keywords: Coliform, Identification, Most probable number, Papaya

Abstrak. Pepaya merupakan buah yang sering dikonsumsi di Indonesia dan mengalami peningkatan konsumsi dari tahun 2015-2016. Pepaya memiliki kandungan air yang tinggi (85-90\%) dan pH mendekati netral. Hal ini menjadikan buah pepaya rentan mengalami kerusakan dan menjadi media yang cocok untuk tumbuhnya mikroba pencemar. Adanya mikroba pencemar pada pepaya ini dapat menimbulkan masalah kesehatan. Penelitian ini untuk mengamati kandungan mikroba pada pepaya potong di kawasan Universitas Sumatera Utara. Penelitian ini dilaksanakan dengan melakukan uji laboratorium dan hasil yang didapatkan berupa gambaran kandungan mikroba pada sampel pepaya potong. Pengujian kandungan *Corresponding author at: Departemen Gizi, Fakultas Kedokteran, Universitas Sumatera Utara E-mail address: 


\begin{abstract}
mikroba koliform pada sampel menggunakan metode Most Probable Number (MPN) dan identifikasi biokimia. Sampel pepaya dipilih dengan menggunakan total sampling yang berasal dari kawasan Universitas Sumatera Utara sejumlah 14 sampel pepaya potong dianalisis pada penelitian ini. Dengan menggunakan uji MPN didapatkan bahwa semua sampel pepaya memiliki ambang batas mikroba melebihi yang ditentukan oleh SNI 7388: 2009 yaitu dibawah <20/g. Sebanyak 9 sampel pepaya (64,28\%) mengandung bakteri Klebsiella sp, 5 sampel (35,72\%) mengandung bakteri E.coli. Bakteri yang ditemukan pada penelitian ini adalah Escherichia coli dan Klebsiella sp. Adanya kandungan mikroba pada sampel pepaya yang melebihi ambang batas tersebut harus menjadi perhatian dari berbagai pihak dalam pengawasan panganan yang dijajakan.
\end{abstract}

Kata Kunci: Koliform, Most probable number, Pepaya, Uji identifikasi Received 12 May 2020| Revised 28 July 2020| Accepted 19 September 2020

\title{
1. Introduction
}

Fruit is essential to be consumed daily to meet the body demands of vitamins, minerals and fiber. The Ministry of Health, In the Balanced Nutrition Guidelines has recommended consumption of 2-3 servings of fruits per day. Lack of fruit and vegetable consumption is associated with poor health and an increased risk of non-communicable diseases. The Increasing risk of gastrointestinal disease by $19 \%$, ischemic heart disease by $31 \%$ and stroke risk by $11 \%$ are due to lack of fruit and vegetable intake [1]. In 2017, around 3.9 million deaths worldwide were caused by inadequate consumption of fruits and vegetables [2].

Indonesia is a tropical country, making it rich in various plant-based food sources. With these abundant plant-based food sources consisting of fruits and vegetables, it is easy for Indonesians to access them. One of the frequently consumed fruit in Indonesia is papaya. According to data supplied by Central Statistical Agency, there was an increase in the average rate of papaya consumption by $0.055 \mathrm{Kg}$ per person in a week in 2016 from the initial number of $0.043 \mathrm{Kg}$ in 2015 [3]. Due to the relatively cheaper price; papaya is also often consumed in sliced pieces.

However, fruit products are easily rotten generally high in developing countries, ranging around $30 \%-50 \%$. This is due to the inadequate comprehension in agricultural handling in most people [4]. Papaya contains high water volume (85-90\%) and $\mathrm{pH}$ 5,3 $\pm 0,7-6,5 \pm$ 0,3 [5], that is quite often vulnerable to easily rotten assist in the emergence of pathogenic microbes. These pathogenic microbes may come from either the food source itself or also the hygiene during food production is closely related to food-borne diseases. Generally 
speaking, the existence of these microbes, food-borne diseases that often affect the gastrointestinal tract, which causes diarrhea, stomachache and vomiting.

Several outbreak cases have occurred several times due to sliced papaya consumption. In 1996, a number of 116 sailors in Singapore were infected with Salmonella Weltevreden and the bacteria were found in samples of sliced papaya that were consumed along with other fruits. Another outbreak occurs ten years later in Australia due to the consumed papaya had been infected with Salmonella Litchfield [6]. Data regarding poisoning cases due to sliced papaya in Indonesia is still undefined. Fruits sold in the form of slices like this are vulnerable because it allows microbes to have reproduced due to high in nutrition [7].

Therefore, the aim of this study is to examine the microbial content of sliced papaya samples sold within the area of Universitas Sumatera Utara in order to provide an overview of the microbial content in papaya samples.

\section{Method}

This study was conducted using a laboratory test with expected outcomes that came in the form of a microbial content overview of sliced papaya samples. This microbial content test was conducted at the Microbiology Laboratory of Faculty of Medicine, Universitas Sumatera Utara and the sample was purchased within the area of the campus, bearing in mind the short distance between the vendors and the laboratory, as to minimize the risk of contamination. The sample size was chosen by using total sampling; the samples came from sliced papaya sold within the campus area. Samples that have been purchased were then put into sterile containers and sent to the Microbiology Laboratory in a period of fewer than 2 hours. Before being tested, $25 \mathrm{~g}$ of papayas were weighed, then diluted by using $225 \mathrm{~mL}$ of Buffered Peptone Water (BPW) $\left(10^{-1}\right.$ dilution). After that, as much as 10 $\mathrm{ml}$ of papaya sample was transferred into a sterile tube.

In order to detect the coliform microbes, the Most Probable Number (MPN) method was used. This method is generally used to calculate the estimated number of microbes in food, water and agricultural products [8]. The first stage of MPN test is a presumptive test that divided into 3 groups of tubes, each contained 5 tubes housing a medium of 10 $\mathrm{mL}$ lactose broth and within each tube, a Durham cylinder was positioned upside down to trap the gas formed. A total of $1 \mathrm{ml}$ of sliced papaya sample was diluted into a second tube comprising of $9 \mathrm{~mL}$ of sterile water $\left(10^{-2}\right.$ dilution) and from the second tube, another $1 \mathrm{ml}$ was taken and diluted back to the third tube containing $9 \mathrm{~mL}$ of sterile water $\left(10^{-3}\right.$ dilution $)$. Every $1 \mathrm{ml}$ from the 1 st dilution tube were moved into group 1 
tube, the 2nd dilution was put into group 2 tube and so on. Then, the lactose broth tube was incubated for $24-48$ hours at $35^{\circ} \mathrm{C} \pm 2^{\circ} \mathrm{C}$.

Lactose broth tube with a positive result (marked by the presence of gas formed), using a loop, transfer the positive culture into the Brilliant Green Bile Lactose Broth (BGBLB) tube that contain an inverted Durham cylinder. Then the tube was incubated for 24-48 hours at a temperature of $35^{\circ} \mathrm{C} \pm 2^{\circ} \mathrm{C}[8,9]$. The positive results were marked with the formation of gas in the Durham cylinder. For bacterial identification, cultures from BGBLB media were planted into Eosin Methylene Blue (EMB) media and a biochemical tests were carried out in the form of indole, urease, motility, Voges-Proskauer, Triple Sugar Iron (TSI), methyl red and Simmon's Citrate.

\section{Result and Discussion}

From this study, 14 samples of papaya were acquired to conduct analysis. Presumptive test, which is the initial stage in microbial content test, used the characteristics of coliform bacteria that can ferment lactose as its carbon source. Fermented lactose can form acids and gas, hence, the results are deemed to be positive and the samples may contain coliform bacteria [10]. With this presumptive test, it can be deducted that all the samples were positive (formation of gas occurred within the Durham cylinder, Table 1).

Table 1. Presumptive test results

\begin{tabular}{|c|c|c|c|c|c|}
\hline \multirow{2}{*}{ Sample } & \multicolumn{3}{|c|}{ Number of positive tube } & \multirow{2}{*}{ MPN } & \multirow{2}{*}{$\begin{array}{l}\text { Microbe } \\
\text { quality }\end{array}$} \\
\hline & $10^{-1} \mathrm{~mL}$ & $10^{-2} \mathrm{~mL}$ & $10^{-3} \mathrm{~mL}$ & & \\
\hline T1 & 5 & 1 & 0 & 33 & Not safe \\
\hline $\mathrm{T} 2$ & 4 & 1 & 1 & 21 & Not safe \\
\hline $\mathrm{T} 3$ & 4 & 1 & 1 & 21 & Not safe \\
\hline $\mathrm{T} 4$ & 5 & 1 & 1 & 46 & Not safe \\
\hline T5 & 3 & 1 & 1 & 14 & Not safe \\
\hline T6 & 5 & 1 & 1 & 46 & Not safe \\
\hline $\mathrm{T} 7$ & 4 & 1 & 1 & 21 & Not safe \\
\hline $\mathrm{T} 8$ & 5 & 1 & 1 & 46 & Not safe \\
\hline T9 & 4 & 1 & 1 & 21 & Not safe \\
\hline $\mathrm{T} 10$ & 5 & 1 & 0 & 33 & Not safe \\
\hline $\mathrm{T} 11$ & 5 & 0 & 1 & 31 & Not safe \\
\hline $\mathrm{T} 12$ & 4 & 1 & 1 & 21 & Not safe \\
\hline $\mathrm{T} 13$ & 5 & 1 & 1 & 46 & Not safe \\
\hline $\mathrm{T} 14$ & 4 & 1 & 1 & 21 & Not safe \\
\hline
\end{tabular}

MPN value of a sample was obtained by using a combination of five tubes that provide positive results. Then, the combination was matched by using the MPN/100mL index table. In this study, a total of 14 samples of papaya have MPN value exceeding the threshold of pathogenic microbes set by SNI 7388: 2009 in fresh fruits, which is 20 
MPN/g for E.coli. This provides us an overview that the papaya samples are not recommended to be consumed raw.

Presumptive tests with positive results can be caused by bacteria other than coliforms, thus, advanced investigation in the form of confirmation test is required by utilizing the BGBLB media. This confirmation test is done to testify the existence of coliform bacteria in the sample [10]. Cultures from lactose broth tubes were planted into BGBLB media that contain gallbladder, served to inhibit Gram-positive bacteria, whereas Brilliant green, used to inhibit certain types of Gram-negative bacilli bacteria so that it helps fertilize coliform bacteria [11].

BGBLB media with positive results were then planted into the EMB Media. This media contains lactose and sucrose as a source of growth for Gram-negative bacteria. Moreover, the content of methylene blue on the media was used to inhibit Gram-positive bacteria and the content of the eosin Y dye may change from colorless to blackish purple due to acidic condition. E.coli bacteria that were cultured on EMB media will give the characteristic of a metallic green colony (Figure 1) [12].

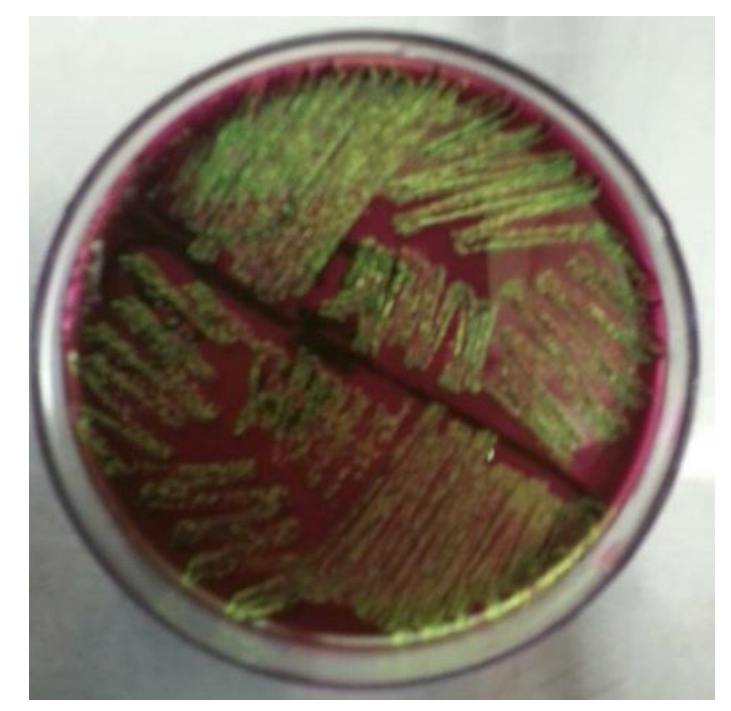

Figure 1. E.coli green metallic colony on EMB media

To find out the type of coliform microbes, an identification test consisting of indole, urease, Simmon's citrate, TSI, methyl red, motility, Voges-Proskauer tests, and confectionery tests were conducted. Based on the biochemical identification test, 9 samples of papaya (64.28\%) contains Klebsiella sp. and 5 samples (35.72\%) of contents E.coli. The two types of bacteria found in this study were of coliform microbial groups. Coliform microbes refer to a group of Gram-negative, rod-shaped, facultative aerobics, non-spore, lactose fermenters can produce gas within 48 hours at $35^{\circ} \mathrm{C}$ [8]. The coliform 
microbes found in this study is more likely to come from contaminated water source or usage of unsterile cutting tools.

A study by Mukhopadhyay at al [13], discovers that $70 \%$ samples of the sliced papaya samples were positive to contain coliform bacteria, and $48 \%$ amongst them was Escherichia coli. Furthermore, in several samples, Salmonella, V.cholerae, and S.aureus were also found. Various microbes, such as molds and lactic acid bacteria can grow in fruits due to the high carbohydrate content and a near-neutral $\mathrm{pH}$. Generally, the number of microbes found in fruits is around $10^{3}-10^{6}$ cell/g and these microbes came from the air, soil, water, and agricultural processing [14]. Similar to other fruits, papaya has a high constituent of water (85-90\%) with an low acid $\mathrm{pH}$ (range: 5,3 $\pm 0,7-6,5 \pm 0,3$ ). This condition can lead to increased risk of pathogenic microbes' growth [5]. Consumption of contaminated papaya, especially with microbes that exceeds the stated threshold, may escalate the risk of being infected with gastrointestinal diseases.

Aside from the fruit itself, the sources of pathogenic microbes may also come from other sources such as the use of contaminated water and the hygiene of tools and vendors. A study by Lubis et al [15], found that in the tools and hands of food-handlers, bacteria such as E.coli, Klabsiella pneumonia, and S.aureus can be found. Thus, it is important for every food-handler needs to ensure their hygiene and also the hygiene of their tools.

\section{Conclusion}

From the results of this study, it was found that almost all samples contaminated by microbes exceeded the established threshold of $20 \mathrm{MPN} / \mathrm{g}$. Bacteria found in this study were Escherichia coli, and Klebsiella sp. The fact that the pathogenic microbes found in the papaya samples exceeded this threshold indicates that, the papaya samples are not suitable for raw consumption; therefore, the public is encouraged to consume mature papaya products. Therefore, supervision is needed among surveillance on food vendors to maintain the hygiene and sanitation of the food they sold.

\section{Acknowledgments}

Thank you to Rhea Tiara Dinata and the Laboratory of Microbiology for their assistance in this research. 


\section{References}

[1] World Health Organization, "Increasing Fruit and Vegetable Consumption to Reduce the Risk of Noncommunicable Diseases,". 2019. Available: https://www.who.int/elena/titles/fruit_vegetables/ncds/en/ [Accessed: May. 13, 2019]

[2] Badan Pusat Statistik, "Konsumsi Buah dan Sayuran Indonesia Susenas Maret 2016", Dalam rangka Hari Gizi Nasional, 25 Januari 2017.

[3] S. Hamidah, "Sayuran dan Buah Serta Manfaatnya Bagi Kesehatan", MAFAZA, Indonesia.

[4] K. Suteki, P. Roedhy, S. Sriani, Sobir, W. D. Widodo, "Karakter fisik dan kimia buah pepaya pada stadia kematangan berbeda," Jurnal Agronomi Indonesia, vol. 38, no. 1, pp. 60-66. 2010. DOI: https://doi.org/10.24831/jai.v38i1.1678

[5] L. K. Strawn, M. D. Danyluk, "Fate of Escherichia coli O157:H7 and Salmonella spp. On fresh and frozen cut mangoes and papaya," International Journal of Food Microbiology, vol. 138, pp.78-84. 2010. DOI: https://doi.org/10.1016/j.ijfoodmicro.2009.12.002

[6] O. S.Qadri, B. Yousuf, A. K. Srivastava, F. Yildiz, "Fresh-cut fruits and vegetables: critical factors influencing microbiology and novel approaches to prevent microbial risks - A review," Cogent Food \& Agriculture, vol. 1. 2015. DOI: $10.1080 / 23311932.2015 .1121606$

[7] M. T. Madigan, J. M. Martinko, K. S. Bender, D. H. Buckley, D. A. Stahl, "Brock Biology of Microorganism", New York: Pearson, 2015.

[8] Badan Standarisasi Nasional, "Metode Pengujian Cemaran Mikroba Dalam Daging, Telur, dan Susu Serta Hasil Olahannya,”. 2008.

[9] J. G. Cappuccino, C. T. Welsh, "Microbiology: A Laboratory Manual" New York: Pearson, 2019.

[10] M. Mishra, A. P. Arukha, A. K. Patel, N. Behera, T. K. Mohanta, D. Yadav, "Multi-drug resistant coliform: water sanitary standards and health hazards" Frontiers in Pharmacology, vol. 9 : 311. DOI: 10.3389/fphar.2018.00311

[11] A. Lal, N. Cheeptham, "Eosin-methylene Blue Agar Plates Protocol". Available at: https://www.asmscience.org/content/education/protocol/protocol.2869 [Accessed: July. 23, 2019].

[12] A. Mukhopadhyay, A. Mitra, R. Roy, A. K. Guha, "An evaluation of street -vended sliced papaya (Carica papaya) for bacteria and Indicator mirco-organism of public health significance" Food Microbiology vol. 19, no. 6pp. 663-667. 2002. DOI: https://doi.org/10.1006/fmic.2002.0511

[13] T. Sopandi, Wardah, "Mikrobiologi Pangan [Teori dan Praktik]”. Yogyakarta: Penerbit Andi, 2014.

[14] N. D. A. Lubis, S. Amelia, N. K. Arrasyid, M. F. Rozi, "Modelling of risk factors associated with foodborne disease among school-aged children in Medan, Indonesia”, Open Access Macedonian Journal of Medical Sciences, vol. 7, no. 19, pp. 3302-3306. 2019. DOI: https://doi.org/10.3889/oamjms.2019.721 